\title{
Pathogenicity and immunogenicity of attenuated, nef-deleted HIV-I strains in vivo
}

Paul R Gorry*1,2,3, Dale A McPhee ${ }^{2,4,6}$, Erin Verity1,4,6, Wayne B Dyer 7,8 , Steven L Wesselingh ${ }^{1,2,3}$, Jennifer Learmont ${ }^{7}$, John S Sullivan ${ }^{7,8}$, Michael Roche ${ }^{1}$, John J Zaunders 9 , Dana Gabuzda11,12, Suzanne M Crowe ${ }^{1,3}$, John Mills ${ }^{3,4,5}$, Sharon R Lewin ${ }^{3,13}$, Bruce J Brew ${ }^{10}$, Anthony L Cunningham ${ }^{14}$ and Melissa J Churchill ${ }^{1}$

Address: ${ }^{1}$ Macfarlane Burnet Institute for Medical Research and Public Health, Melbourne, Victoria, Australia, ${ }^{2}$ Department of Microbiology and Immunology, University of Melbourne, Melbourne, Victoria, Australia, ${ }^{3}$ Department of Medicine, Monash University, Melbourne, Victoria, Australia, ${ }^{4}$ Department of Microbiology, Monash University, Melbourne, Victoria, Australia, ${ }^{5}$ Department of Epidemiology \& Community Medicine, Monash University, Melbourne, Victoria, Australia, ${ }^{6}$ National Serology Reference Laboratory, St. Vincent's Institute for Medical Research, Fitzroy, Victoria, Australia, ${ }^{7}$ Australian Red Cross Blood Service, Sydney, New South Wales, Australia, ${ }^{8}$ Faculty of Medicine, University of Sydney, Sydney, New South Wales, Australia, ${ }^{9}$ Center for Immunology, St. Vincent's Hospital, Sydney, New South Wales, Australia, ${ }^{10}$ Department of Neurology, St. Vincent's Hospital, Sydney, New South Wales, Australia, ${ }^{11}$ Dana-Farber Cancer Institute, Boston, MA, USA, ${ }^{12}$ Department of Neurology, Harvard Medical School, Boston, MA, USA, ${ }^{13}$ Infectious Diseases Unit, Alfred Hospital, Melbourne, Victoria, Australia and ${ }^{14}$ Westmead Millennium Institute, Westmead, New South Wales, Australia

Email: Paul R Gorry* - gorry@burnet.edu.au; Dale A McPhee - dale@nrl.gov.au; Erin Verity - erin.verity@csl.com.au; Wayne B Dyer - WDyer@arcbs.redcross.org.au; Steven L Wesselingh - stevew@burnet.edu.au;

Jennifer Learmont - JLearmont@arcbs.redcross.org.au; John S Sullivan - JSullivan@arcbs.redcross.org.au;

Michael Roche - mroche@burnet.edu.au; John J Zaunders - j.zaunders@cfi.unsw.edu.au; Dana Gabuzda - dana_gabuzda@dfci.harvard.edu; Suzanne M Crowe - crowe@burnet.edu.au; John Mills - mills@portsea.net; Sharon R Lewin - s.lewin@alfred.org.au;

Bruce J Brew - b.brew@unsw.com.au; Anthony L Cunningham - tony_cunningham@wmi.usyd.edu.au;

Melissa J Churchill - churchil@burnet.edu.au

* Corresponding author

Published: 23 September 2007

Retrovirology 2007, 4:66 doi:10.1186/1742-4690-4-66
Received: 6 July 2007

Accepted: 23 September 2007

This article is available from: http://www.retrovirology.com/content/4/I/66

(c) 2007 Gorry et al; licensee BioMed Central Ltd.

This is an Open Access article distributed under the terms of the Creative Commons Attribution License (http://creativecommons.org/licenses/by/2.0), which permits unrestricted use, distribution, and reproduction in any medium, provided the original work is properly cited.

\begin{abstract}
In efforts to develop an effective vaccine, sterilizing immunity to primate lentiviruses has only been achieved by the use of live attenuated viruses carrying major deletions in nef and other accessory genes. Although live attenuated HIV vaccines are unlikely to be developed due to a myriad of safety concerns, opportunities exist to better understand the correlates of immune protection against HIV infection by studying rare cohorts of long-term survivors infected with attenuated, nef-deleted HIV strains such as the Sydney blood bank cohort (SBBC). Here, we review studies of viral evolution, pathogenicity, and immune responses to HIV infection in SBBC members. The studies show that potent, broadly neutralizing anti-HIV antibodies and robust CD8+ T-cell responses to HIV infection were not necessary for long-term control of HIV infection in a subset of SBBC members, and were not sufficient to prevent HIV sequence evolution, augmentation of pathogenicity and eventual progression of HIV infection in another subset. However, a persistent T-helper proliferative response to HIV p24 antigen was associated with long-term control of infection. Together, these results underscore the importance of the host in the eventual outcome of infection. Thus, whilst generating an effective antibody and CD8+ T-cell response are an essential component of vaccines aimed at preventing primary HIV infection, T-helper responses may be important in the generation of an effective therapeutic vaccine aimed at blunting chronic HIV infection.
\end{abstract}




\section{Introduction}

Despite considerable effort, all attempts to develop an effective human immunodeficiency virus (HIV) vaccine based on subunit or prime-boost strategies have failed to elicit sterilizing immunity and protect against infection with wild type virus (reviewed in [1-3]). Current World Health Organization estimates indicate 42 million people are infected with HIV and approximately 20 million have died from AIDS. Approximately 5 million new infections occur annually. The overwhelming majority of these individuals live in developing countries with little or no access to potentially lifesaving antiretroviral therapies. Moreover, HIV is predicted to become the leading burden of disease in middle and low income countries by 2015 [4]. Thus, the need for an effective preventative and/or therapeutic HIV vaccine has never been more urgent.

Since the discovery of HIV nearly 25 years ago, there have been significant advances in our knowledge of HIV immunology (reviewed in [5-7]). As early as 1990 subunit vaccines based on the HIV envelope protein were developed, based on the observation that vaccinated chimpanzees were protected against homologous HIV challenge [8]. However, it is unlikely that such vaccines will ever be able to illicit immune responses sufficient for protection against heterologous HIV strains and, in fact, these approaches have failed repeatedly in animal models. In addition, HIV envelope protein-based vaccines were not efficacious in 2 phase III vaccine trials in humans [9-12]. More sophisticated vaccine approaches have targeted cellular immunity by the development of DNA prime-boost strategies, and have achieved strong stimulation of antibody and cytotoxic T-lymphocyte (CTL) responses in monkeys. However, despite robust immunological responses, these strategies have ultimately failed to protect against challenge infection. A better understanding of the correlates of immune protection against HIV infection would greatly assist efforts to develop an effective HIV vaccine $[13,14]$.

In addition to envelope and DNA prime-boost vaccines, various other strategies have been adopted in HIV vaccine development including the use of recombinant viral and bacterial vectors, synthetic peptides, live attenuated virus, and whole inactivated HIV particles. These strategies have been reviewed in detail recently $[1-3,15]$, and are summarized in Figure 1. Other innovative vaccine strategies that have been recently explored include the use of peptideloaded dendritic cells [16], and non-infectious viral particles surface-engineered to produce antigen presenting particles that mimic antigen presenting cells [17] to induce cellular immune responses. To date, sterilizing immunity to primate lentiviruses has only been achieved by the use of live attenuated simian immunodeficiency virus (SIV) and chimeric simian-HIV (SHIV) vaccines carrying major

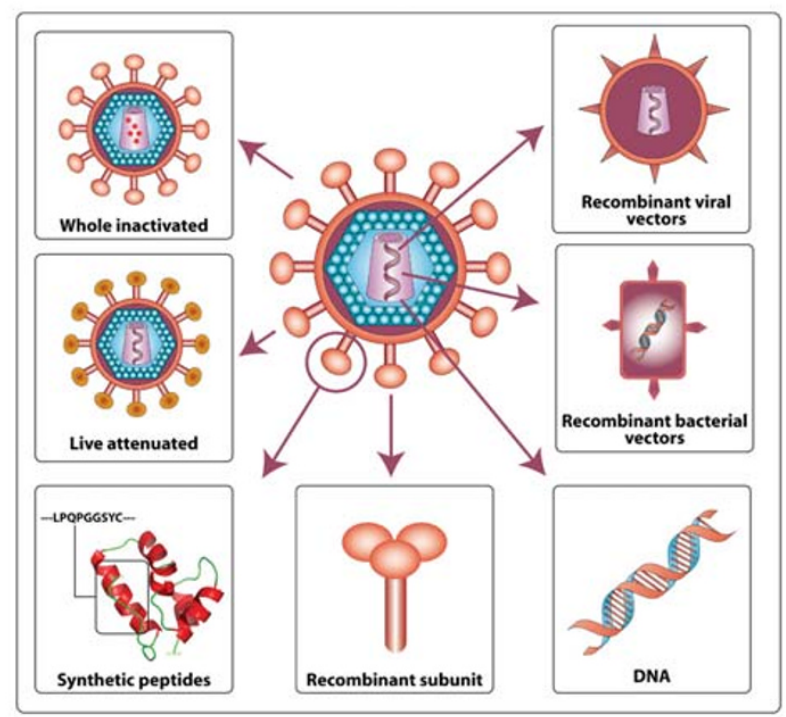

\section{Figure I}

Various approaches for HIV vaccine development. The various approaches used in past and present HIV vaccine strategies that are summarized here have been described in detail previously [I-3, I5].

deletions in the nef gene and other accessory genes [1821]. Passive infusion of broadly-neutralizing monoclonal antibodies in HIV animal models have also been shown to confer complete protection against challenge infection [22-25]. This provides proof of principle that protection against infection is possible with use of the appropriate antigen. However, nef-deleted virus is unlikely to be considered safe enough for use as a HIV vaccine, either because immunization may pose an immediate risk to individuals with weak immune systems, or because the attenuated vaccine strain could eventually evolve to a more pathogenic form [14]. Both of these outcomes have been demonstrated in macaque studies, whereby some animals vaccinated with nef-deleted SIV progressed to AIDS in the absence of wild type virus challenge infection $[26,27]$. Moreover, some individuals infected with nefdeleted HIV strains eventually experience CD4+ T-cell loss after many years of asymptomatic infection [28-31]. Nonetheless, studies of long-term survivors (LTS) naturally "vaccinated" with nef-deleted HIV, such as the Sydney blood bank cohort (SBBC) [32] and other rare cohorts [33-37], may provide unique insights into protective antibody and CTL responses, which may assist HIV vaccine development [14].

\section{Epidemiology and Clinical History of the Sydney blood bank cohort}

The SBBC consists of 8 individuals (subjects C98, C54, C49, C64, C18, C135, C83 and C124) who became 
infected with an attenuated strain of HIV via contaminated blood products from a common blood donor (subject D36) between 1981 and 1984 [30,32,38]. The SBBC blood transfusion recipients have been referred to as recipients $7,13,12,9,10,4,8$, and 5 , respectively, in one previous study [30] and subjects A (C18), B (C64), C (C98), D (C54), E (C49) and F (C83) in an earlier publication [38]. Viral attenuation has been attributed to gross deletions in the nef/long terminal repeat (LTR) region of the HIV genome [32]. The clinical history and laboratory studies of the subjects from the first identification as SBBC members through 1998 has been described previously [30], and a detailed update of the clinical and laboratory data through 2006 has been described recently [39]. Briefly, despite being infected from a single source, SBBC members now comprise slow progressors (SP) who have eventually experienced decline in CD4 T-cells after many years of asymptomatic infection (subjects D36, C98, C54), and "elite" long-term nonprogressors (LTNP) who have had stable CD4 T-cell counts and low or below detectable plasma HIV RNA levels for more than 20 years without antiretroviral therapy (ART) and remain asymptomatic (subjects C49, C64, C135) [28,30,31]. Five SBBC members have died of causes either unrelated to- or not directly related to HIV infection (C98, C54, C18, C83, C124) (Table 1). The SBBC therefore provides a unique opportunity to study the pathogenesis of, and immune responses to nef-deleted HIV infection in a naturally occurring human setting.

\section{HIV isolates and viral phenotypes}

To determine whether changes in viral phenotype were occurring in SBBC members, HIV isolation was attempted from peripheral blood mononuclear cells (PBMC) collected longitudinally from all subjects except $\mathrm{C} 124$ and C83 $[28,40]$, by selected PBMC coculture techniques [40,41] (Table 2). For subjects with detectable but low HIV RNA levels (D36, C54, C98, C18), more than 10 HIV isolates were obtained from each of D36, C54 and C98 over a 5 to 6 year period between November 1994 and November 2000 [40]. Three HIV isolates were obtained from C18 over an 8 month period between July 1993 and March 1994. For subjects with consistently undetectable HIV RNA levels (C49, C64, C124, and C135), a single isolate was obtained from C64 from PBMC collected in February 1996. This was despite isolation attempts from 16 additional PBMC collections between November 1995 and March 2001 [40]. All isolates carried similar but distinct deletion mutations in the nef gene and LTR region $[28,29,32,42]$, and were unable to synthesize Nef proteins detectable by Western blotting or immunofluorescence staining of infected cells (D. McPhee and A. Greenway, unpublished data). No isolates were obtained from longitudinal samples of PBMC collected from C49 or C135 over a 4 to 7 year period between February 1994 and October 2000, or from a single sample of PBMC obtained from C124 in March 1993 [40]. Thus, success of isolating nef-deleted HIV from SBBC members was strongly dependent on the presence of detectable plasma HIV RNA levels, with few exceptions.

Table I: Clinical history of SBBC members

\begin{tabular}{|c|c|c|c|c|c|}
\hline Subject & Sex & $\begin{array}{l}\text { Date of } \\
\text { Birth }\end{array}$ & $\begin{array}{l}\text { Date } \\
\text { Transfused }\end{array}$ & Antiretroviral Drugs ${ }^{a}$ & Clinical History and other information ${ }^{a}$ \\
\hline D36 & M & $6 / 4 / 1958$ & $\begin{array}{l}\text { N/A; infected } \\
\text { with HIV-I } \\
\text { sexually, I2/I980 }\end{array}$ & $\begin{array}{l}\text { ABC, AZT, NVP (1/1999- } \\
\text { 9/2004) ABC, NVP, 3TC } \\
\text { (9/2004-present) }\end{array}$ & Diagnosed with moderate HIVD, I2/I998; SP. \\
\hline $\mathrm{C} 98$ & M & $7 / 11 / 1937$ & $1 / 2 / 1982$ & $\begin{array}{l}\text { D4T, NVP, IND (I I/I999- } \\
\text { death) }\end{array}$ & $\begin{array}{l}\text { Prednisone since } 1995 \text { for asthma; died 3/30/200I from } \\
\text { bronchial amyloidosis; death not related to HIV; SP. }\end{array}$ \\
\hline C54 & M & $2 / 17 / 1928$ & $7 / 24 / 1984$ & None & $\begin{array}{l}\text { IDDM; HCV; surgery for colon cancer in 1995; died 8/28/ } \\
200 \text { I from myocardial infarct; death not related to HIV; SP. }\end{array}$ \\
\hline C49 & $\mathrm{F}$ & $6 / 9 / 1954$ & $6 / 11 / 1984$ & None & $\begin{array}{l}\text { Diagnosed with age-onset diabetes in } 2004 \text {, managed by } \\
\text { diet; chronic alcoholism; LTNP. }\end{array}$ \\
\hline C64 & $\mathrm{F}$ & $3 / 20 / 1926$ & $5 / 4 / 1983$ & None & Hypertension; hypercholesterolemia; LTNP. \\
\hline $\mathrm{Cl} 35$ & M & $2 / 23 / 1946$ & $2 / 11 / 1981$ & None & CCR5 32 heterozygote; HLA-B57 positive; LTNP. \\
\hline $\mathrm{Cl} 8$ & M & $10 / 12 / 1912$ & $8 / 31 / 1983$ & None & $\begin{array}{l}\text { Severe coronary atherosclerosis; died I I/I995 from } \\
\text { bacterial pneumonia; death not related to HIV; LTNP. }\end{array}$ \\
\hline C83 & $\mathrm{F}$ & $12 / 21 / 1964$ & $12 / 30 / 1982$ & None & $\begin{array}{l}\text { Prednisone since I } 982 \text { for SLE; intermittent } \\
\text { cyclophosphamide, azathioprine, hydrocortisone; died } \\
\text { from combined PCP and pneumococcal pneumonia 4/I } 987 \text {; } \\
\text { uncertain if death was HIV related; HIV Progression status } \\
\text { uncertain }\end{array}$ \\
\hline $\mathrm{Cl} 24$ & $\mathrm{~F}$ & $9 / 30 / 1917$ & $4 / 29 / 1981$ & None & $\begin{array}{l}\text { Died from metastatic gastric cancer 10/1994. Death not } \\
\text { related to HIV; HIV Progression status uncertain. }\end{array}$ \\
\hline
\end{tabular}

Dates shown are day/month/year. M, male; F, female; ABC, abacavir; AZT, zidovudine; NVP, nevirapine; 3TC, lamivudine; N/A, not applicable; HIVD, HIV associated dementia; SP, slow progressor; LNTP, long-term nonprogressor; IDDM, insulin-dependent diabetes melitis; SLE, systemic

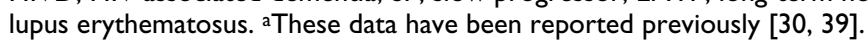


Table 2: Phenotypes of nef-deleted viruses isolated from SBBC members, and corresponding laboratory data

\begin{tabular}{|c|c|c|c|c|c|c|c|}
\hline Subject & Virus isolate & Date & $\begin{array}{l}\text { Years post- } \\
\text { infection }\end{array}$ & $\begin{array}{l}\text { CD4 cells } \\
\text { (cells/ } \mu \mathrm{l})\end{array}$ & $\begin{array}{l}\text { HIV RNA } \\
\text { (copies/ml) }\end{array}$ & $\begin{array}{l}\text { Replication in } \\
\text { PBMC }\end{array}$ & $\begin{array}{l}\text { Coreceptor } \\
\text { usage }\end{array}$ \\
\hline \multirow[t]{11}{*}{ D36 } & D36II & $6 / 5 / 95$ & 14.4 & N/A & 1400 & ++ & $\begin{array}{l}\text { CCR5, CXCR4, } \\
\text { (CCR2b) }\end{array}$ \\
\hline & D36III & $8 / 2 / 96$ & 15.2 & 609 & 1100 & ++ & NT \\
\hline & D36IV & $10 / 4 / 96$ & 15.3 & 504 & 7700 & ++ & NT \\
\hline & D36V & $9 / 7 / 96$ & 15.6 & 414 & 2600 & ++ & NT \\
\hline & $\mathrm{D} 36 \mathrm{VI}$ & $23 / 10 / 96$ & 15.8 & 432 & 1100 & ++ & NT \\
\hline & D36VII & $30 / 1 / 97$ & 16.1 & 361 & 3200 & ++ & NT \\
\hline & D36VIII & $20 / 5 / 97$ & 16.4 & 540 & 4000 & ++ & $\begin{array}{l}\text { CCR5, CXCR4, } \\
\text { (CCR2b) }\end{array}$ \\
\hline & D36IX & $23 / 12 / 97$ & 17.0 & 390 & 7500 & ++ & $\begin{array}{l}\text { CCR5, CXCR4, } \\
\text { (CCR2b) }\end{array}$ \\
\hline & D36X & $15 / 7 / 98$ & 17.6 & 325 & $\mathrm{~N} / \mathrm{A}$ & ++ & NT \\
\hline & D36XI & $22 / 1 / 99$ & 18.1 & $\mathrm{~N} / \mathrm{A}$ & N/A & ++ & $\begin{array}{l}\text { CCR5, CXCR4, } \\
\text { (CCR2b) }\end{array}$ \\
\hline & D36XVI & $8 / 11 / 00$ & 19.9 & $\mathrm{~N} / \mathrm{A}$ & $\mathrm{BD}$ & ++ & CCR5 \\
\hline \multirow[t]{3}{*}{$\mathrm{Cl} 8$} & $\mathrm{Cl}(2)$ & $26 / 7 / 93$ & 9.8 & N/A & N/A & +++ & $\begin{array}{l}\text { CCR5, (CCR3, } \\
\text { GprI5) }\end{array}$ \\
\hline & $\mathrm{Cl} 8(3)$ & $14 / 10 / 93$ & 10.1 & N/A & $\mathrm{N} / \mathrm{A}$ & +++ & NT \\
\hline & $\mathrm{Cl} 8(4)$ & $7 / 3 / 94$ & 10.5 & $\mathrm{~N} / \mathrm{A}$ & 2804 & +++ & $\begin{array}{l}\text { CCR5, (CCR3, } \\
\text { GprI5) }\end{array}$ \\
\hline \multirow[t]{12}{*}{ C54 } & C54III & $7 / 11 / 94$ & 10.3 & 2006 & 8200 & $+/-$ & $\begin{array}{l}\text { CCR5, (CCR2b, } \\
\text { CCR3) }\end{array}$ \\
\hline & C54IV & $21 / 6 / 95$ & 10.9 & 1504 & 3000 & $+/-$ & NT \\
\hline & C54 V & $20 / 12 / 95$ & 11.4 & 1054 & 400 & $+/-$ & NT \\
\hline & C54VI & $4 / 3 / 96$ & 11.7 & 1188 & 1500 & $+/-$ & NT \\
\hline & C54VII & $19 / 6 / 96$ & 11.9 & 972 & 3600 & $+/-$ & NT \\
\hline & C54VIII & $16 / 9 / 96$ & 12.2 & 1120 & 1800 & $+/-$ & $\begin{array}{l}\text { CCR5, (CCR2b, } \\
\text { CCR3) }\end{array}$ \\
\hline & C54X & $3 / 3 / 97$ & 12.7 & 882 & 3400 & $+/-$ & NT \\
\hline & C54XI & 14/5/97 & 12.8 & 1286 & N/A & $+/-$ & NT \\
\hline & C54XII & $1 \mathrm{I} / 8 / 97$ & 13.1 & 1419 & 1700 & $+/-$ & NT \\
\hline & C54XIII & $|7 /| \mid / 97$ & 13.3 & 1054 & N/A & $+/-$ & NT \\
\hline & C54XIV & $5 / 5 / 99$ & 14.8 & 1288 & 1200 & $+/-$ & $\begin{array}{l}\text { CCR5, (CCR2b, } \\
\text { CCR3) }\end{array}$ \\
\hline & C54XV & $6 / 3 / 00$ & 15.7 & 840 & 1600 & $+/-$ & NT \\
\hline \multirow[t]{13}{*}{ C98 } & C98II & $7 / 12 / 94$ & 12.9 & 426 & 1000 & ++ & CCR5, (CCR3) \\
\hline & C98III & $9 / 10 / 95$ & 13.8 & 576 & 670 & ++ & NT \\
\hline & C98IV & $7 / 2 / 96$ & 14.1 & 435 & 200 & ++ & NT \\
\hline & $\mathrm{C} 98 \mathrm{~V}$ & $22 / 5 / 96$ & 14.3 & 693 & 290 & ++ & NT \\
\hline & C98VI & $7 / 8 / 96$ & 14.6 & 512 & 330 & ++ & $\begin{array}{l}\text { CCR5, (CCR2b, } \\
\text { CCR3) }\end{array}$ \\
\hline & C98VII & $4 / 11 / 96$ & 14.8 & 646 & 690 & ++ & NT \\
\hline & C98VIII & $31 / 1 / 97$ & 15.0 & 629 & 770 & ++ & NT \\
\hline & C98IX & $7 / 5 / 97$ & 15.3 & 529 & 760 & ++ & NT \\
\hline & C98X & $27 / 8 / 97$ & 15.6 & 612 & 170 & ++ & NT \\
\hline & C98XI & $26 / 11 / 97$ & 15.8 & 400 & $N / A$ & ++ & NT \\
\hline & C98XII & $30 / 9 / 98$ & 16.7 & $N / D$ & N/A & ++ & NT \\
\hline & C98XIII & $3 / 3 / 99$ & 17.2 & 476 & $\mathrm{~N} / \mathrm{A}$ & ++ & NT \\
\hline & C98XIV & $9 / 11 / 99$ & 17.8 & 585 & $\mathrm{BD}$ & ++ & $\begin{array}{l}\text { CCR5, (CCR2b, } \\
\text { CCR3) }\end{array}$ \\
\hline C64 & C64IV & $28 / 2 / 96$ & 12.8 & 850 & $\mathrm{BD}$ & $+/-$ & CCR5 \\
\hline
\end{tabular}

Dates shown are day/month/year. CD4 cells were measured by flow cytometry. Plasma HIV-I RNA was measured by COBAS Amplicor HIV-I Monitor Version I.0 (Roche Molecular Diagnostic Systems, Branchburg, N.J.) prior to July 1999 and Version I.5 after July I999. HIV-I RNA levels < 400 copies $/ \mathrm{ml}$ (Version I) or < 50 copies/ml (Version I.5) were considered below detection. BD, below detection; N/A, not available; NT, not tested. +++, replication kinetics similar to wild type primary HIV strains; ++, reduced levels of replication and/or delayed replication kinetics compared to wild type primary HIV strains; +/-, levels of HIV replication barely detectable or not detectable by RT assays, but detectable by measurement of extracellular p24 antigen [40]. 
When compared with wild type HIV isolates and isogenic controls with mutations in nef, replication capacity of SBBC isolates in PHA-activated PBMC was found to be consistent over time by viruses isolated from a particular subject, but heterogenous between subjects and fell into 3 distinct phenotypes $[28,40]$ (Table 2). Viruses isolated from C18 replicated rapidly to high levels similar to wild type HIV; viruses isolated from D36 and C98 replicated to lower levels; and viruses isolated from C54 and C64 were barely able to replicate to detectable levels. In contrast, all isolates replicated to equivalent levels in the Cf2-luc reporter cell line $[41,43,44]$ expressing CD4, CCR5 and CXCR4. Thus, SBBC isolates except those from C18 appear to have attenuated replication capacity in PHAactivated PBMC. Inhibiting the in vivo replication of HIV in D36 by HAART demonstrated a prolonged in vivo virion half life, with a first-phase slope of decline of HIV RNA 0.18 /day [45] which is slower than that seen in all previously studied individuals infected with wild-type HIV after commencement of ART [46-49]. Thus, the replication kinetics of D36 virus appears to be attenuated both in vitro and in vivo.

Analysis of coreceptor usage in transfected Cf2-Luc cells [41] showed that all isolates used CCR5 (R5) as the primary coreceptor for HIV entry, except viruses isolated from D36 prior to commencement of HAART which were dual tropic and used CCR5 and CXCR4 (R5X4) [28,40] (Table 2). These results showed that nef-deleted HIV was capable of undergoing a coreceptor switch from R5 to $\mathrm{R} 5 \mathrm{X} 4$ in vivo. An isolate obtained from D36 after commencement of HAART was CCR5-restricted and had features of an early archived HIV variant, but was genetically similar to HIV present in a CSF sample obtained from D36 during HIV-associated dementia (HIVD) [28]. Thus, for D36, HIV present in CSF during HIVD was likely to be an early variant that underwent compartmentalized evolution in the CNS. Moreover, we showed for the first time that nef-deleted HIV is inherently capable of undergoing compartmentalized evolution in the CNS and causing neurologic disease in humans [28]. Stepwise quasispecies diversity was observed in SBBC SP, whereas C49 displayed stable quasispecies diversity most similar to early variants in the SBBC (B. Herring et al., manuscript submitted). Extended analysis of alternative coreceptor usage showed that D36 and C54 isolates could use CCR2b, C18 and C54 isolates could use CCR3, and C18 isolates could use Gpr15 for HIV entry, albeit at low levels [40] (Table 2). Whether expanded usage of alternative HIV coreceptors by SBBC isolates contributes to HIV pathogenesis in these individuals is uncertain, but the unique signature of coreceptor usage for viruses isolated from different SBBC members suggests independent evolution for each virus after infection of each cohort member. This interpretation is consistent with results of Env heteroduplex tracking assays, Env heteroduplex mobility assays and Env V1V2 length polymorphism assays which also demonstrated independent evolution of HIV Env in each subject ([50], and B. Herring et al., manuscript submitted).

\section{Changes in HIV pathogenicity}

To better understand changes in pathogenicity which may have contributed to HIV progression in D36, Jekle et al [51] used an ex vivo human lymphoid cell culture system to analyze the ability of 2 HIV viruses isolated from D36 to deplete CD4+ T-cells; one isolated in 1995 prior to the onset of AIDS (D36II) and another isolated in 1999 after the onset of disease progression (D36XI) (Table 2). Although both D36 isolates were less potent in depleting CD4+ T-cells than reference X4 and R5X4 isolates with intact nef genes, the 1999 isolate induced greater levels of CD4+ T-cell cytotoxicity than the 1995 isolate. Differences in CD4+ T-cell cytotoxicity between the 2 isolates were evident in CD4+/CCR5- cells, but not evident in CD4+/ CCR5+ cells suggesting an increased ability to use CXCR4 by the 1999 isolate. Further studies with the CXCR4 inhibitor AMD3100 showed that, although both isolates were functionally R5X4 [28,40] (Table 2), the 1999 isolate had preferential use of CXCR4 whereas the 1995 isolate had preferential use of CCR5 for HIV entry. These studies showed evolution of R5X4 strains in D36 to a variant with higher cytopathic potential that was associated with increased use of CXCR4 in vitro and HIV progression in vivo.

Consistent with results of the study by Jekle et al [51], we showed alterations in HIV cytopathicity by sequential D36 isolates in cultures of monocyte-derived macrophages (MDM). Compared with the highly macrophage tropic R5 ADA and R5X4 89.6 isolates, all D36 viruses replicated in MDM to low levels and had delayed replication kinetics [52]. There was no evidence of increased HIV replication in MDM by virus isolated from D36 after HIV progression. However, in support of the results obtained by Jekle et al [51], the 1999 isolate caused extensive cytopathicity in MDM similar to that present in cultures infected with ADA or 89.6, characterized by the presence of many syncytia [52]. In contrast, earlier D36 isolates caused only few or occasional syncytia in MDM despite all D36 viruses replicating in MDM to similar levels. Thus, increased cytopathicity in MDM by the 1999 D36 isolate is most likely due to intrinsic pathogenic features of the Env that increase fusogenicity, similar to that which has been observed by particular neurotropic R5 and R5X4 viruses [53-55]. The increased Env fusogenicity may have contributed to greater cytopathicity by the 1999 D36 isolate and HIV progression in D36. Further studies to elucidate the molecular determinants of D36 Env that are associated with increased fusogenicity are in progress. 


\section{T-cell pathogenesis}

The effect of long-term infection with nef-deleted virus on CD4+ T cells was studied in detail for six SBBC members [56]. Careful comparison with age- and transfusionmatched controls revealed the surprising result that SBBC members had an increased number of circulating $\mathrm{CD} 45 \mathrm{RO}+$ memory CD4+ T cells. This was unexpected, since these CD4+ T cells are widely believed to represent the main target of cytopathic HIV infection [57-60] (reviewed in [61]), and loss of these cells ultimately leads to acquired immunodeficiency. Therefore, this result is consistent with the hypothesis that nef-deleted HIV has reduced pathogenicity in vivo.

Nevertheless, in the SBBC subjects studied with detectable plasma viral load, C54 and C98, there was concomitant elevation of CD8+ T cell activation, whereas the SBBC subjects with undetectable plasma viral load, C49, C64 and $\mathrm{C} 135$ had normal levels of $\mathrm{CD} 8+\mathrm{T}$ cell activation [56]. Therefore, within the SBBC, the situation was similar to the strong correlation seen between plasma viral load and CD8+ T-cell activation in subjects infected with wild type HIV [62]. Furthermore, as described above, subjects D36, C98 and C54 exhibited a clear CD4+ T cell decline, albeit at a relatively slow rate [28-30]. This interesting finding argues that pathogenicity within the SBBC was more closely correlated with levels of viral replication (as assessed by plasma viral load) and CD8+ T-cell activation than with viral pathogenicity dictated by the presence or absence of nef. This finding likely represents the ability of host factors to modulate the pathogenicity of nef-deleted HIV-1 [63,64]. CD8+ T cell activation may reflect lymphocyte turnover during HIV infection, which has been proposed to lead to disruption of normal homeostasis and eventual consumption of both memory and naïve CD4+ T cells $[65,66]$. However, we did not find evidence of dramatically increased CD4+ T cell turnover in these subjects, as determined by expression of Ki-67 as a marker of cell proliferation [56].

\section{Evolution of nef/LTR sequence}

To determine whether an evolving nef/LTR sequence contributed to HIV progression in D36 and C98, we undertook a detailed longitudinal analysis of nef and LTR sequence changes occurring in D36, C98, C49, C54 and C64 over a 4 to 10 year period [29]. Sequential analysis of $n e f /$ LTR demonstrated a gradual loss of nef sequence that differed in magnitude between subjects. A large deletion of 128 bp emerged in D36 effectively removing the entire $n e f$ gene with the exception of the region surrounding the nef start codon, the polypurine tract which contains terminal signals for HIV integration, and a 90 bp region of the $n e f /$ LTR overlap region surrounding the negative regulatory element. The pattern of nef/LTR sequence loss in C98 was remarkably similar to that of D36. The pattern of nef
/LTR sequence loss in C54 was also similar, but less extensive than that observed in D36 and C98. However, the additional loss of nef/LTR sequence in C64 was comparatively minimal. These data are illustrated in Figure 2, where the nef/LTR sequences cloned from the earliest available and most recent blood samples of these subjects are compared. A more detailed longitudinal analysis of $n e f /$ LTR sequences in these subjects has been reported in Churchill et al [29]. Thus, viruses harboured by D36, C54, C98 and C64 appeared to be evolving in a convergent fashion toward a highly deleted, minimal nef/LTR structure containing only sequence elements that are absolutely essential for HIV replication [29]. The convergent

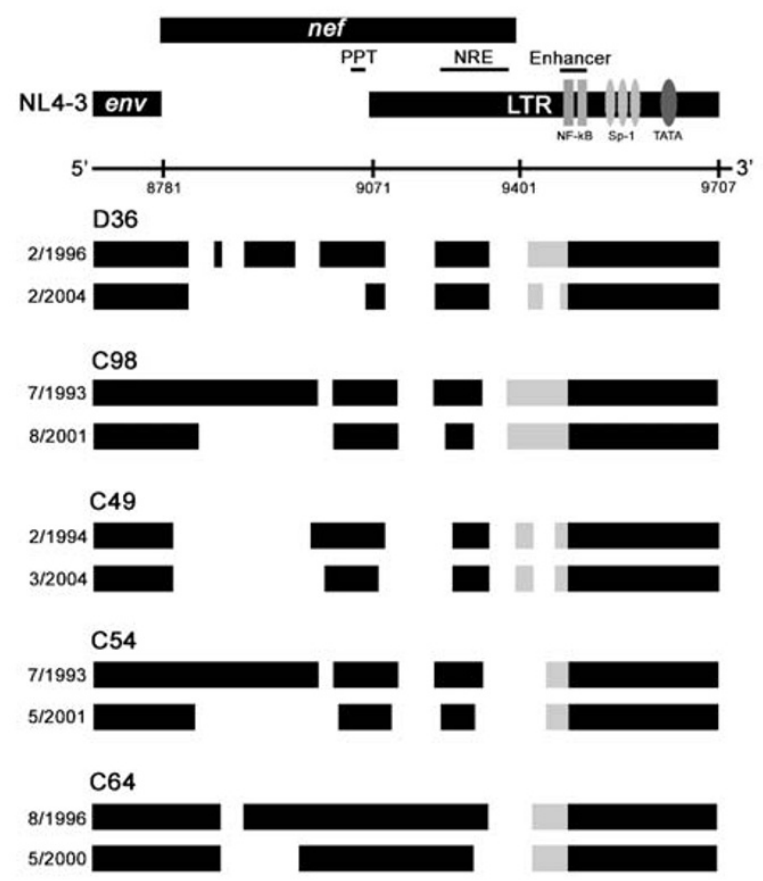

Figure 2

Convergent evolution of SBBC nefILTR sequences. Comparisons of the genomic structures of the nef/LTR sequences cloned from the earliest available and most recently obtained PBMC samples of D36, C98, C49, C54 and C64 are shown. The genomic structures are compared to wild type HIV (NL4-3). Numbers refer to nucleotide positions in NL4-3. Black boxes represent intact sequence, and gaps represent deletions. Grey blocks represent sequence areas containing alterations of NF- $\mathrm{KB}$ and $\mathrm{Sp}-\mathrm{I}$ binding sites in the LTR. The dates shown represent the times when PBMC were collected for analysis. PPT, polypurine tract; NRE, negative regulatory unit. This figure has been published previously [29], and is reproduced here with permission from the American society for microbiology. 
nature of the nef/LTR sequence changes implies the presence of strong selection pressures that maintains the ability of defective HIV genomes to persist in vivo. The highly evolved nef/LTR sequences harboured by D36, C54 and C98 were strikingly similar to those that remained dominant in C49 for at least 10 years (Fig. 2) [29]. Thus, the highly evolved nef/LTR structure appears to be stable, and in the case of $\mathrm{C} 49$ does not increase pathogenicity. However, taken together the results suggest the in vivo pathogenicity of nef-deleted HIV harboured by SBBC members is dictated by factors other than those that impose a unidirectional selection pressure on the nef/LTR region of the HIV genome. Due to the changes in the nef/LTR region, these other presumably host factors become more important in terms of disease outcome. This is exemplified by the marked variation from no disease progression with no detectable virus replication (C49 and C64), to no progression with a low viral load (C54), through to slow progression (D36 and C98).

Reversion to pathogenicity by nef-deleted SIV has been associated with restoration of a truncated Nef protein [26], acquisition of further deletions in the nef/LTR overlap region [67], and/or duplications of NF-kB binding sites in the LTR [67]. In contrast to the SIV studies, the in vivo evolution of nef-deleted HIV in SBBC members was unidirectional toward a smaller nef/LTR sequence and the majority of the additional sequence loss was within the nef-alone region [29]. Furthermore, none of the clones were capable of encoding Nef. Together, these results suggest improved viral replication by further deleting remnants of the nef gene. In addition, the presence of duplicated NF- $\mathrm{\kappa B}$ binding sites in the LTR was not associated with clinical status of the SBBC subjects. Therefore, it is likely that viral factors that modulate the in vivo pathogenicity of nef-deleted HIV will be distinct from those in nef-deleted SIV. Interestingly, the unidirectional evolution toward the minimal nef/LTR sequence observed in SBBC members was strikingly similar to the pattern of evolution in a slow progressor infected with a nef/LTR-deleted variant of HIV circulating recombinant form 01_AE [34]. The convergent pattern of $n e f /$ LTR evolution among viruses harboured by SBBC members is therefore unlikely to be due to a unique property of the infecting strain, but rather a positive selection that is common across clades.

\section{Changes in transcriptional activity}

Viruses harbored by SBBC members contain unique alterations of NF- $\mathrm{KB}$ and Sp-1 binding sites in the LTR that may affect transcriptional activity and thus, replication capacity $[28,29,32]$. Therefore, we examined the nucleotide sequence and transcriptional activity of nef/LTR clones obtained sequentially from D36 blood samples and from D36 CSF obtained during HIVD, to determine whether changes in LTR activity may contribute to neuropathogen- esis of nef-deleted HIV-1 infection [68]. We found that the transcriptional activity of CSF-derived nef/LTR clones was up to 4.5 -fold higher than blood-derived clones isolated before and during HIVD when tested under basal, PMAand Tat-activated conditions. The presence of duplicated $\mathrm{NF}-\kappa \mathrm{B}$ and $\mathrm{Sp}-1$ binding sites or a truncated nef sequence in blood-derived nef/LTRs was not sufficient to mediate large increases in transcriptional activity. However, CSFderived $n e f /$ LTRs had duplicated NF- $\kappa$ B and Sp-1 binding sites coupled with a truncated nef sequence, which formed a regulatory unit that significantly enhanced LTR transcription [68].

Previous studies showed that LTR variants with augmented transcriptional activity enhance replication of HIV [69]. Therefore, to determine whether D36 nef/LTRs affect replication capacity of HIV in vitro, we produced and characterized full-length chimeric molecular clones of HIV NL4-3 carrying the nef/LTR nucleotide sequence of blood-derived D36 nef/LTRs or the CSF-derived D36 nef/ LTR [68]. We examined the capacity of chimeric NL4-3 viruses carrying D36 nef/LTRs to replicate in PBMC compared with wild type NL4-3 and the NL4-3 $\Delta$ Nef deletion mutant [70]. Compared to wild type NL4-3, chimeric HIV containing the nef/LTR sequence of blood derived D36 viruses had attenuated replication kinetics, similar to NL4-3 $\Delta$ Nef. In contrast, chimeric HIV containing the nef/ LTR of D36 CSF had enhanced replication capacity compared to wild type NL4-3. Thus, the nef/LTR derived from CSF of D36, which had augmented basal, PMA- and Tatactivated transcriptional activity compared to wild type and blood-derived D36 nef/LTRs, augmented replication of HIV in PBMC. Together, our results suggest unique features of the CSF-derived nef/LTR restore efficient replication capacity of nef-deleted HIV in PBMC by enhancing transcription. The results further suggest that nef and LTR mutations that augment transcription may contribute to neuropathogenesis of nef-deleted HIV.

\section{Attenuation in other HIV genes}

In addition to nef and LTR, mutations or polymorphisms in other HIV genes including gag, rev, tat, vif, vpr, vpu and env have been detected in SP or LTNP [71-78]. A previous study of HIV rev alleles isolated from a subject with longterm nonprogressive HIV infection showed a persistent Leu to Ile change at position 78 in the Rev activation domain which attenuated Rev function and HIV replication capacity [73], providing evidence that defective rev alleles may contribute to long-term survival of HIV infection in some patients. A subsequent study of naturally occurring rev alleles with rare sequence variations in the activation domain showed variable reductions in Rev activity [79], although it was unclear from this study whether the observed reductions in Rev activity would be sufficient to attenuate HIV replication capacity. Of note, 
CTL escape mutations in the second coding exon of Tat have been shown to attenuate virus in vivo, suggesting that in vivo sequence changes in other regulatory HIV-1 genes may potentially affect HIV-1 pathogenesis [80]. Since differences in HIV pathogenicity in SBBC members could not be fully explained by alterations in the nef/LTR region [29] or Env phenotype $[40,50]$, we characterized dominant HIV-1 rev alleles that persisted in SBBC LTNP $(\mathrm{C} 18, \mathrm{C} 64)$ and SP $(\mathrm{C} 98, \mathrm{D} 36)$ [81]. We found that the ability of Rev derived from D36 and C64 to bind the Rev responsive element (RRE) in RNA binding assays was reduced by approximately $90 \%$ compared to Rev derived from NL4-3, C18 or C98. D36 Rev also had a $50-60 \%$ reduction in ability to express Rev-dependent reporter constructs in mammalian cells. In contrast, C64 Rev had only marginally decreased Rev function despite attenuated RRE binding. In D36 and C64, we found that attenuated RRE binding was associated with rare amino acid changes at 3 highly conserved residues; Gln to Pro at position 74 immediately $\mathrm{N}$-terminal to the Rev activation domain, and Val to Leu and Ser to Pro at positions 104 and 106 at the Rev C-terminus, respectively. In D36, reduced Rev function and altered replication capacity was mapped to an unusual 13 amino acid extension at the Rev C-terminus. However, database analysis of rev sequence demonstrated that the presence of one or more of these rare amino acid changes was not able to discriminate between subjects with progressive or non-progressive HIV-1 infection. Moreover, none of these amino acid changes occurred in a previously identified LTNP with defective rev alleles [73]. Thus, our studies suggest the contribution of any or all of these mutations to decreased RRE binding and/or attenuated Rev function by SBBC Revs, and possibly to slow or absent HIV progression, is likely to be context dependent.

It is presently unclear whether attenuated D36 Rev function in vitro equates to attenuated Rev function in vivo, and indeed whether attenuated Rev function contributed to slow progression of HIV infection in this subject. Extrapolation of these in vitro findings to an in vivo role for attenuated D36 rev alleles is difficult, since this subject and other SBBC members are infected with virus containing gross nef/LTR deletions which have been shown to cause significant viral attenuation in this cohort $[28,29,32]$. Nonetheless, our findings raise the possibility that attenuated Rev function may contribute, at least in part, to viral attenuation and slow HIV progression in D36.

\section{Anti-HIV Ig responses}

To better understand the humoral immune response to nef-deleted HIV infection, we measured the total IgG responses in longitudinal plasma samples of SBBC members by Western blotting, and compared these with total IgG responses in a control group of LTNP with intact nef genes [40]. We found a good correlation between total IgG responses in SBBC members and a detectable plasma VL, with plasma from C18, C54, D36 and C98 all being strongly reactive. Subjects $\mathrm{C} 49$ and C64, who consistently maintained undetectable HIV RNA copy numbers $[29,30]$, had significantly reduced total IgG responses. Furthermore, subject C135, who has also had consistently undetectable HIV RNA levels has not fully seroconverted after more than 20 years of infection [40,42]. These studies highlight the importance of adequate antigenic stimulation by nef-deleted HIV to drive antibody production. In contrast, we found that total IgG responses in the control group were uniformly potent, reflecting the fact that all these individuals had detectable VLs. Among SBBC members, the strongest antibody responses were observed in individuals with low but detectable VL set points, less than approximately $10,000 \mathrm{RNA}$ copies/ml. This is consistent with a recent observation of an undetectable $\mathrm{VL}$ and weak, delayed antibody responses in an unrelated individual with nef-deleted HIV [34].

Recent studies have highlighted the change in HIV antibody responses with respect to antibody isotype switching after initial infection, in particular $\operatorname{IgG}_{3}$ reactivity to $\mathrm{p} 24$ $[82,83]$. Preliminary WB testing of p24 $\mathrm{IgG}_{3}$ responses in the SBBC LTNP indicated there was reactivity for those individuals with the most potent total IgG responses (C18 and C54) (E. Verity, D. McPhee, K. Wilson, and D. Zotos, unpublished data). This hints at delayed isotype switching and hence delayed maturation of immune responses for at least some members of the SBBC.

\section{Neutralization studies of nef-deleted HIV}

In additional studies, we determined whether plasma from SBBC members had differences in ability to neutralize nef-deleted HIV strains. We did this by comparing the ability of longitudinally collected plasma from SBBC members or from control LTNP cohort members to neutralize the infectivity of HIV isolated from D36 and C18 [40]. We found that, for SBBC plasmas, neutralization of D36 or C18 viruses strongly correlated with VL, replication capacity of the isolated virus, and the strength of antiHIV IgG responses. Plasma from SBBC members with undetectable VL was unable to neutralize the infectivity of these viruses. In contrast, plasmas from the control LTNP cohort were able to neutralize the infectivity of SBBC viruses with titres generally higher than that seen for SBBC members, but there was no correlation between neutralization and HIV RNA copy number or IgG responses in the control LTNP group.

\section{Broad neutralizing antibody responses}

A number of studies have suggested an increased frequency of LTNP and long term survivors (LTS) possess strong, cross-reactive neutralising antibody responses [84- 
86]. However, very few studies have investigated antibody responses in LTNP/LTS infected with nef-deleted HIV, despite a number of studies showing strong neutralising antibody responses in macaques infected with nef-deleted SIV [87-92]. However, studies by Greenough et al., [93] showed measurable neutralising antibody responses concurrent with a detectable VL for a single individual infected with nef-defective HIV. We therefore determined the breadth of neutralizing antibodies against HIV for SBBC members.

We found that plasma from $\mathrm{C} 18$, and to a lesser extent D36, C54 and C98 were able to potently neutralize the infectivity of a number of laboratory adapted and primary HIV strains, but little or no neutralizing activity was evident in plasma from C49, C64 and C135 [40]. Further analysis of cross reacting neutralizing antibodies in SBBC plasma demonstrated that plasma derived from $\mathrm{C} 18$ was able to potently neutralize the infectivity of HIV- $1_{\text {ROK39 }}$ (clade A), HIV-1 $1_{\text {SE364 }}$ (clade C), HIV-1 $1_{\text {BCB93 }}$ (clade D), and HIV-1 ${ }_{92 \mathrm{TH}}{ }_{24}$ (CRF01_AE), while plasma derived from C98 was able to only weakly neutralize the infectivity of HIV- $1_{\text {ROK39 }}$ and HIV- $1_{\text {SE364 }}[40]$.

Together, our studies on antibody responses in SBBC members demonstrated that infection with nef-deleted HIV can, in some individuals, induce antibody responses capable of potently neutralizing a broad range of isolates. It is possible that the breadth of antibody responses observed in SBBC members may be associated with unrestricted immunoglobulin class switching, which is inhibited by Nef [94]. This would be counterbalanced by the very low viral replication in vivo (VL) and a detectable $\operatorname{IgG}_{3}$ p24 response for $\mathrm{C} 18$ and C54. Hence, the broad antibody response may also reflect an early response to infection. The strongest antibody responses in SBBC members were observed in individuals with a detectable $\mathrm{VL}$, supporting the model of a VL threshold which must be reached to provide adequate antigenic stimulation to drive antibody production [14]. However, this higher level of virus replication places these individuals at greatest risk of disease progression. Signs of disease progression were observed for 2 SBBC members (D36, C98) [2830], demonstrating that the potent neutralizing antibody responses observed did not protect from disease progression. These results question the effectiveness of a broad neutralizing antibody response in individuals with established infection. However, this does not preclude an important role for neutralizing antibodies in preventing initial infection.

\section{T-cell responses}

Analysis of cellular immune mechanisms suppressing nefdeleted virus in SBBC nonprogressors may provide insights relevant for HIV vaccine design. Several studies have demonstrated that the presence of a sustained Gagspecific CD8+ T-cell response is associated with protection against disease progression in cohorts of LTNP infected with nef-intact HIV [95-97]. In support, our studies have also shown that the distinguishing feature of LTNP harbouring nef-intact HIV is the predominance of Gag-specific CD8+ T-cell responses, which decline when these individuals start to progress (W.B. Dyer et al., manuscript in preparation). However, novel qualitative and quantitative differences in immune correlates of viral control may exist in LTNP infected with nef-deleted HIV. Longitudinal studies of T-cell responses in SBBC members have demonstrated a dominance of Pol-specific CD8+ T-cell responses rather than those against Gag [98] and W.B. Dyer et al., manuscript in preparation). This suggests that infection with nef-deleted HIV may give rise to a qualitatively different response, although a subset of SBBC members also had strong CD8+ T-cell responses to Gag [98]. Nonetheless, CD8+ T-cell responses to Gag or Pol did not discriminate SBBC LTNP from SP.

In contrast, longitudinal analysis of HIV-specific CD4+ Tcells showed that all SBBC nonprogressors able to completely control plasma HIV RNA levels to below detectable levels (C49, C64 and C135) had persistent and strong Thelper proliferative responses to HIV p24 antigen, whereas these responses were absent in all progressors with persistent viremia (C54, C98 and D36) (Fig. 3). The notable exception was $\mathrm{C} 18$ who had detectable but low plasma HIV RNA levels without evidence of CD4+ T-cell loss, and had detectable p24 T-helper responses over a short period of approximately 12 months leading up to his non-HIV related death at 83 years of age. In this subject, the p24 T-helper responses coincided with an exponential increase in CTL responses against Pol antigens, measured by memory CTL precursor frequency assay [98], and IFN-gamma ELISPOT responses (W. Dyer, unpublished data). However, it is difficult to interpret the significance of the T-cell responses in $\mathrm{C} 18$ given the short window of analysis. Together, although derived from a small cohort of individuals, these results suggest that immune suppression of nef-deleted HIV-1 by SBBC LTNP may be dependent upon persistent T-helper responses irrespective of the CD8+ T-cell and neutralizing antibody response to viral antigens.

\section{Conclusion}

The development of an effective HIV vaccine has been hampered by the lack of defined correlates of immune protection against HIV infection. Although nef-deleted strains of HIV are not suitable as live attenuated HIV vaccines due to safety concerns, the only lentiviral vaccines to date that have generated sterilizing immunity in animals are those based on live, attenuated viruses. To this end, studies of SBBC members naturally "vaccinated" with nef- 


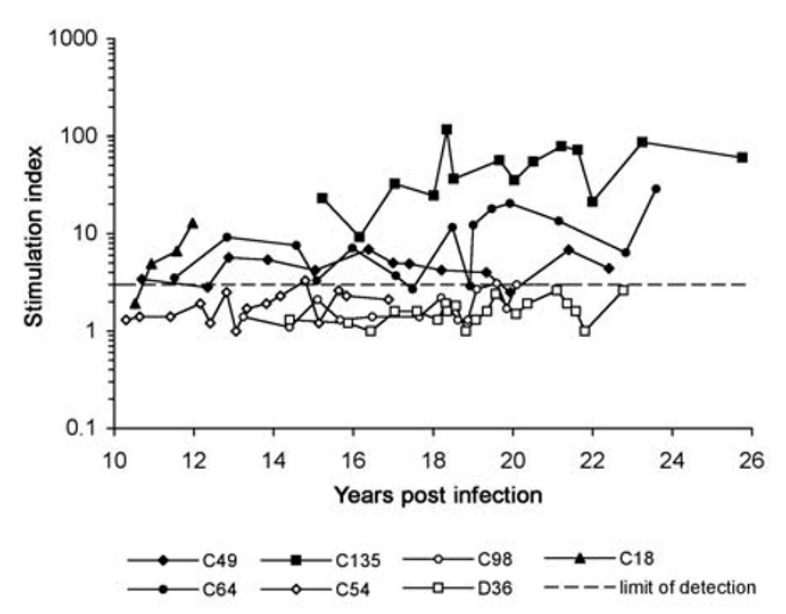

Figure 3

Longitudinal analysis of $\mathrm{T}$-helper proliferative responses to HIV p24 antigen in SBBC progressors and nonprogressors. T-helper proliferative responses to HIV p24 antigen were determined by $\left[{ }^{3} \mathrm{H}\right]$-thymidine incorporation, as described previously [99, 100]. T-helper responses were persistently detectable (stimulation index $>$ 3 ) in all nonprogressing subjects with below detectable plasma HIV RNA levels (CI35, C64, and C49), but absent in all progressors (D36, C98, and C54). Of note, T-helper responses were detectable over a short window in C18, who was a nonprogressing individual with detectable plasma HIV RNA levels.

deleted HIV may provide unique insights into protective immune responses to HIV infection, which may assist the development of an effective HIV vaccine. As a consortium, we have been studying nef-deleted HIV infection in the SBBC for a number of years, linking changes in pathogenicity in vivo with viral evolution and immune responses to infection. The major aim of this review was to summarize our recently published and unpublished studies on the SBBC. Together, the studies show that potent, broadly neutralizing anti-HIV antibodies and robust CD8+ T-cell responses to HIV infection were not necessary for long-term control of HIV infection in a subset of SBBC members, and were not sufficient to prevent HIV sequence evolution, augmentation of pathogenicity and eventual progression of HIV infection in another subset. However, a strong T-helper proliferative response to HIV p24 antigen was associated with long-term control of infection. Variation in the outcome of HIV infection in this cohort appears to be strongly host-dependent, consistent with other studies with wild-type HIV. Dependence upon the host's unique immune environment also appears to be important in contributing to control of infection. This further complicates development of a successful vaccine. We hope that results gleaned thus far from studies of this unique cohort of individuals will provide HIV vaccine researchers with novel insights into immune mechanisms that may serve to prevent or control HIV infection.

\section{Competing interests}

The author(s) declare that they have no competing interests.

\section{Authors' contributions}

The SBBC project is a multicenter consortium. PRG, DAM, JL, JSS, SMC, JM, BJB, ALC and MJC are principal SBBC investigators who, along with SRL contributed to the study design, analysis and interpretation of the data. EV performed the neutralization studies and helped determine the viral phenotypes. WBD and JJZ performed the Tcell experiments. MJC performed the nef cloning and sequencing. MR provided technical expertise and contributed intellectually. DG performed the viral phenotyping in conjunction with PRG. PRG wrote the manuscript. All authors helped edit the manuscript. All authors have seen and approved the final manuscript.

\section{Acknowledgements}

We thank Marcel Hijnen for assistance with artwork. This study was supported in part by a multicenter program grant to SLW, SMC, SRL, BJB and ALC from the Australian National Health and Medical Research Council (NHMRC) (358399), grants to PRG from the Australian NHMRC (25I520, 433915) and NIH/NIAID (AI054207), a grant to DAM from the American Foundation for AIDS Research (amfAR) (106669) and by a grant to MJC from the Australian National Center for HIV Virology Research. PRG is the recipient of an NHMRC R. Douglas Wright Biomedical Career Development Award.

\section{References}

I. Duerr A, Wasserheit JN, Corey L: HIV vaccines: new frontiers in vaccine development. Clin Infect Dis 2006, 43(4):500-5I I.

2. Letvin NL: Progress and obstacles in the development of an AIDS vaccine. Nat Rev Immunol 2006, 6( I 2):930-939.

3. McMichael AJ: HIV vaccines. Annu Rev Immunol 2006, 24:227-255.

4. Mathers $C D$, Loncar D: Projections of global mortality and burden of disease from 2002 to 2030. PLoS Med 2006, 3(II):e442.

5. Chinen J, Shearer WT: Molecular virology and immunology of HIV infection. J Allergy Clin Immunol 2002, I I 0(2): 189-198.

6. Letvin NL, Walker BD: Immunopathogenesis and immunotherapy in AIDS virus infections. Nat Med 2003, 9(7):86 I-866.

7. Spearman P: Current progress in the development of HIV vaccines. Curr Pharm Des 2006, I 2(9): I I 47- I I67.

8. McMichael AJ, Hanke T: HIV vaccines 1983-2003. Nat Med 2003, 9(7):874-880.

9. Flynn NM, Forthal DN, Harro CD, Judson FN, Mayer KH, Para MF: Placebo-controlled phase 3 trial of a recombinant glycoprotein 120 vaccine to prevent HIV-I infection. J Infect Dis 2005, |9|(5):654-665.

10. Gilbert PB, Ackers ML, Berman PW, Francis DP, Popovic V, Hu DJ, Heyward WL, Sinangil F, Shepherd BE, Gurwith M: HIV-I virologic and immunologic progression and initiation of antiretroviral therapy among HIV-I-infected subjects in a trial of the efficacy of recombinant glycoprotein 120 vaccine. I Infect Dis 2005, 192(6):974-983.

II. Gilbert PB, Peterson ML, Follmann D, Hudgens MG, Francis DP, Gurwith M, Heyward WL, Jobes DV, Popovic V, Self SG, Sinangil F, Burke $D$, Berman PW: Correlation between immunologic responses to a recombinant glycoprotein I 20 vaccine and incidence of 
HIV-I infection in a phase 3 HIV-I preventive vaccine trial. J Infect Dis 2005, 19 I(5):666-677.

12. Graham BS, Mascola JR: Lessons from failure--preparing for future HIV-I vaccine efficacy trials. J Infect Dis 2005, I 9 I(5):647-649.

13. Pantaleo G, Koup RA: Correlates of immune protection in HIVI infection: what we know, what we don't know, what we should know. Nat Med 2004, I0(8):806-8I0.

14. Whitney JB, Ruprecht RM: Live attenuated HIV vaccines: pitfalls and prospects. Curr Opin Infect Dis 2004, I 7(I): 17-26.

15. Singh M: No vaccine against HIV yet--are we not perfectly equipped? Virol / 2006, 3:60

16. Klase Z, Donio MJ, Blauvelt A, Marx PA, Jeang KT, Smith SM: A peptide-loaded dendritic cell based cytotoxic T-lymphocyte (CTL) vaccination strategy using peptides that span SIV Tat, Rev, and Env overlapping reading frames. Retrovirology 2006, 3:1.

17. Mosca JD, Chang YN, Williams G: Antigen-presenting particle technology using inactivated surface-engineered viruses: induction of immune responses against infectious agents. Retrovirology 2007, 4:32.

18. Wyand MS, Manson K, Montefiori DC, Lifson JD, Johnson RP, Desrosiers RC: Protection by live, attenuated simian immunodeficiency virus against heterologous challenge. J Virol 1999, 73(10):8356-8363.

19. Wyand MS, Manson KH, Garcia-Moll M, Montefiori D, Desrosiers RC: Vaccine protection by a triple deletion mutant of simian immunodeficiency virus. J Virol 1996, 70(6):3724-3733.

20. Daniel MD, Kirchhoff F, Czajak SC, Sehgal PK, Desrosiers RC: Protective effects of a live attenuated SIV vaccine with a deletion in the nef gene. Science 1992, 258(5090): |938-|94|

21. Almond N, Kent K, Cranage M, Rud E, Clarke B, Stott E): Protection by attenuated simian immunodeficiency virus in macaques against challenge with virus-infected cells. Lancet 1995 345(896I): I342-I344.

22. Baba TW, Liska V, Hofmann-Lehmann R, Vlasak J, Xu W, Ayehunie S, Cavacini LA, Posner MR, Katinger H, Stiegler G, Bernacky BJ, Rizvi TA, Schmidt R, Hill LR, Keeling ME, Lu Y, Wright JE, Chou TC, Ruprecht RM: Human neutralizing monoclonal antibodies of the IgGI subtype protect against mucosal simian-human immunodeficiency virus infection. Nat Med 2000, 6(2):200-206.

23. Ferrantelli F, Rasmussen RA, Buckley KA, Li PL, Wang T, Montefiori DC, Katinger H, Stiegler G, Anderson DC, McClure HM, Ruprecht RM: Complete protection of neonatal rhesus macaques against oral exposure to pathogenic simian-human immunodeficiency virus by human anti-HIV monoclonal antibodies. $J$ Infect Dis 2004, I 89( ( 2):2167-2173.

24. Mascola JR, Lewis MG, Stiegler G, Harris D, VanCott TC, Hayes D, Louder MK, Brown CR, Sapan CV, Frankel SS, Lu Y, Robb ML, Katinger $\mathrm{H}$, Birx DL: Protection of Macaques against pathogenic simian/human immunodeficiency virus 89.6PD by passive transfer of neutralizing antibodies. J Virol 1999, 73(5):4009-4018.

25. Mascola JR, Stiegler G, VanCott TC, Katinger H, Carpenter CB, Hanson CE, Beary H, Hayes D, Frankel SS, Birx DL, Lewis MG: Protection of macaques against vaginal transmission of a pathogenic HIV-I/SIV chimeric virus by passive infusion of neutralizing antibodies. Nat Med 2000, 6(2):207-2 I0.

26. Sawai ET, Hamza MS, Ye M, Shaw KE, Luciw PA: Pathogenic conversion of live attenuated simian immunodeficiency virus vaccines is associated with expression of truncated Nef. J Virol 2000, 74(4):2038-2045.

27. Hofmann-Lehmann R, Vlasak J, Williams AL, Chenine AL, McClure HM, Anderson DC, O'Neil S, Ruprecht RM: Live attenuated, nefdeleted SIV is pathogenic in most adult macaques after prolonged observation. Aids 2003, 17(2): 157-166.

28. Churchill M, Sterjovski J, Gray L, Cowley D, Chatfield C, Learmont J, Sullivan JS, Crowe SM, Mills J, Brew BJ, Wesselingh SL, McPhee DA, Gorry PR: Longitudinal analysis of nef/long terminal repeatdeleted HIV-I in blood and cerebrospinal fluid of a long-term survivor who developed HIV-associated dementia. J Infect Dis 2004, I 90( I 2):2|8|-2| 86

29. Churchill MJ, Rhodes DI, Learmont JC, Sullivan JS, Wesselingh SL, Cooke IR, Deacon NJ, Gorry PR: Longitudinal analysis of human immunodeficiency virus type I nef/long terminal repeat sequences in a cohort of long-term survivors infected from a single source. J Virol 2006, 80(2): 1047-1052.

30. Learmont JC, Geczy AF, Mills J, Ashton LJ, Raynes-Greenow CH, Garsia RJ, Dyer WB, Mclntyre L, Oelrichs RB, Rhodes DI, Deacon NJ, Sullivan JS: Immunologic and virologic status after 14 to 18 years of infection with an attenuated strain of HIV-I. A report from the Sydney Blood Bank Cohort. N Engl] Med 1999, 340(22): $1715-1722$.

3I. Birch MR, Learmont JC, Dyer WB, Deacon NJ, Zaunders J], Saksena $\mathrm{N}$, Cunningham AL, Mills J, Sullivan JS: An examination of signs of disease progression in survivors of the Sydney Blood Bank Cohort (SBBC). J Clin Virol 200I, 22(3):263-270.

32. Deacon NJ, Tsykin A, Solomon A, Smith K, Ludford-Menting M, Hooker DJ, McPhee DA, Greenway AL, Ellett A, Chatfield C, Lawson VA, Crowe S, Maertz S, Sonza S, Learmont J, Sullivan JS, Cunningham A, Dwyer D, Dowton D, Mills J: Genomic structure of an attenuated quasi species of HIV-I from a blood transfusion donor and recipients. Science 1995, 270(5238):988-99|.

33. Kirchhoff F, Greenough TC, Brettler DB, Sullivan JL, Desrosiers RC: Brief report: absence of intact nef sequences in a long-term survivor with nonprogressive HIV-I infection. N Engl J Med 1995, 332(4):228-232.

34. Kondo $M$, Shima $T$, Nishizawa $M$, Sudo $K$, Iwamuro $S$, Okabe $T$, Takebe $Y$, Imai M: Identification of attenuated variants of HIV. I circulating recombinant form 0 I_AE that are associated with slow disease progression due to gross genetic alterations in the nef/long terminal repeat sequences. Journal of Infectious Diseases 2005, 192:56-6I.

35. Mariani R, Kirchhoff F, Greenough TC, Sullivan JL, Desrosiers RC, Skowronski J: High frequency of defective nef alleles in a longterm survivor with nonprogressive human immunodeficiency virus type I infection. J Virol 1996, 70( I I):7752-7764.

36. Rhodes DI, Ashton L, Solomon A, Carr A, Cooper D, Kaldor J, Deacon N: Characterization of three nef-defective human immunodeficiency virus type I strains associated with long-term nonprogression. Australian Long-Term Nonprogressor Study Group. J Virol 2000, 74(22): $1058 \mid-10588$.

37. Salvi R, Garbuglia AR, Di Caro A, Pulciani S, Montella F, Benedetto A: Grossly defective nef gene sequences in a human immunodeficiency virus type I-seropositive long-term nonprogressor. J Virol 1998, 72(5):3646-3657.

38. Learmont J, Tindall B, Evans L, Cunningham A, Cunningham P, Wells J, Penny R, Kaldor J, Cooper DA: Long-term symptomless HIV1 infection in recipients of blood products from a single donor. Lancet 1992, 340(8824):863-867.

39. Gorry PR, Churchill M, Learmont J, Cherry C, Dyer WB, Wesselingh SL, Sullivan JS: Replication-dependent pathogenicity of attenuated, nef-deleted HIV-I in vivo. Journal of Acquired Immune Deficiency Syndromes 2007:In press.

40. Verity E, Zotos D, Wilson K, Chatfield C, Lawson VA, Dwyer D, Cunningham A, Learmont J, Dyer W, Sullivan J, Churchill M, Wesselingh SL, Gabuzda D, Gorry PR, McPhee D: Viral phenotypes and antibody responses in long term survivors infected with attenuated human immunodeficiency virus type I containing deletions in the nef/long terminal repeat region. J Virol 2007, 81:9268-9278.

4I. Gorry PR, Bristol G, Zack JA, Ritola K, Swanstrom R, Birch CJ, Bell JE, Bannert N, Crawford K, Wang H, Schols D, De Clercq E, Kunstman K, Wolinsky SM, Gabuzda D: Macrophage Tropism of Human Immunodeficiency Virus Type I Isolates from Brain and Lymphoid Tissues Predicts Neurotropism Independent of Coreceptor Specificity. I Virol 200I, 75(2I): 10073-10089.

42. Rhodes D, Solomon A, Bolton W, Wood J, Sullivan J, Learmont J, Deacon N: Identification of a new recipient in the Sydney Blood Bank Cohort: a long-term HIV type I-infected seroindeterminate individual. AIDS Res Hum Retroviruses 1999 , I5(16): 1433-1439.

43. Etemad-Moghadam B, Sun Y, Nicholson EK, Fernandes M, Liou K, Gomila R, Lee J, Sodroski J: Envelope glycoprotein determinants of increased fusogenicity in a pathogenic simian-human immunodeficiency virus (SHIV-KB9) passaged in vivo. J Virol 2000, 74(9):4433-4440.

44. Gray L, Sterjovski J, Churchill M, Ellery P, Nasr N, Lewin SR, Crowe SM, Wesselingh S, Cunningham AL, Gorry PR: Uncoupling coreceptor usage of human immunodeficiency virus type I (HIV. I) from macrophage tropism reveals biological properties of 
CCR5-restricted HIV-I isolates from patients with acquired immunodeficiency syndrome. Virology 2005, 337:384-398.

45. Crowe SM, Ho DD, Marriott D, Brew B, Gorry PR, Sullivan JS, Learmont J, Mills J: In vivo replication kinetics of a nef-deleted strain of HIV-I. Aids 2005, I 9(8):842-843.

46. Perelson AS, Essunger P, Cao Y, Vesanen M, Hurley A, Saksela K, Markowitz M, Ho DD: Decay characteristics of HIV-I-infected compartments during combination therapy. Nature 1997, 387(6629): $|88-| 9 \mid$.

47. Perelson AS, Neumann AU, Markowitz M, Leonard JM, Ho DD: HIVI dynamics in vivo: virion clearance rate, infected cell lifespan, and viral generation time. Science 1996 27I(5255): I582-I586.

48. Wei X, Ghosh SK, Taylor ME, Johnson VA, Emini EA, Deutsch P, Lifson JD, Bonhoeffer S, Nowak MA, Hahn BH, et al.: Viral dynamics in human immunodeficiency virus type I infection. Nature 1995, 373(65 I0): I 17-122.

49. Wu H, Kuritzkes DR, McClernon DR, Kessler H, Connick E, Landay A, Spear G, Heath-Chiozzi M, Rousseau F, Fox L, Spritzler J, Leonard JM, Lederman MM: Characterization of viral dynamics in human immunodeficiency virus type I-infected patients treated with combination antiretroviral therapy: relationships to host factors, cellular restoration, and virologic end points. J Infect Dis 1999, 179(4):799-807.

50. Gray L, Churchill MJ, Sterjovski J, Witlox K, Learmont J, Sullivan JS, Wesselingh SL, Gabuzda D, Cunningham AL, McPhee DA, Gorry PR: Phenotype and envelope gene diversity of nef-deleted HIV-I isolated from long term survivors infected from a single source. Virology Journal 2007, 4:75.

51. Jekle A, Schramm B, Jayakumar P, Trautner V, Schols D, De Clercq E, Mills , Crowe SM, Goldsmith MA: Coreceptor phenotype of natural human immunodeficiency virus with nef deleted evolves in vivo, leading to increased virulence. J Virol 2002, 76(1 4):6966-6973.

52. Gorry PR, McPhee DA, Wesselingh SL, Churchill MJ: Macrophage tropism and cytopathicity of HIV-I variants isolated sequen tially from a long-term survivor infected with nef-deleted virus. The Open Microbiology Journal 2007, I:I-7.

53. Gorry PR, Taylor J, Holm GH, Mehle A, Morgan T, Cayabyab M, Farzan M, Wang H, Bell JE, Kunstman K, Moore JP, Wolinsky SM, Gabuzda D: Increased CCR5 affinity and reduced CCR5/CD4 dependence of a neurovirulent primary human immunodeficiency virus type I isolate. Journal of Virology 2002 76(I 2):6277-6292.

54. Ohagen A, Ghosh S, He J, Huang K, Chen Y, Yuan M, Osathanondh R, Gartner S, Shi B, Shaw G, Gabuzda D: Apoptosis induced by infection of primary brain cultures with diverse human immunodeficiency virus type $I$ isolates: evidence for a role of the envelope. Journal of Virology 1999, 73(2):897-906.

55. Peters PJ, Bhattacharya J, Hibbitts S, Dittmar MT, Simmons G, Bell J Simmonds P, Clapham PR: Biological analysis of human immunodeficiency virus type I R5 envelopes amplified from brain and lymph node tissues of AIDS patients with neuropathology reveals two distinct tropism phenotypes and identifies envelopes in the brain that confer an enhanced tropism and fusigenicity for macrophages. J Virol 2004, 78( I3):69|5-6926.

56. Zaunders JJ, Geczy AF, Dyer WB, Mclntyre LB, Cooley MA, Ashton LJ, Raynes-Greenow CH, Learmont J, Cooper DA, Sullivan JS: Effect of long-term infection with nef-defective attenuated HIV type I on CD4+ and CD8+ T lymphocytes: increased CD45RO+CD4+ $T$ lymphocytes and limited activation of CD8+ T lymphocytes. AIDS Res Hum Retroviruses 1999. I5(I7):1519-1527.

57. Chun TW, Chadwick K, Margolick J, Siliciano RF: Differential susceptibility of naive and memory CD4+ $T$ cells to the cytopathic effects of infection with human immunodeficiency virus type I strain LAI. J Virol I997, 7 I (6):4436-4444.

58. Harouse JM, Gettie A, Tan RC, Blanchard J, Cheng-Mayer C: Distinct pathogenic sequela in rhesus macaques infected with CCR5 or CXCR4 utilizing SHIVs. Science I999, 284(54I5):8|6-8|9.

59. Lapenta C, Parlato S, Spada M, Santini SM, Rizza P, Logozzi M, Proietti E, Belardelli F, Fais S: Human lymphoblastoid CD4(+) T cells become permissive to macrophage-tropic strains of human immunodeficiency virus type I after passage into severe combined immunodeficient mice through in vivo upregula- tion of CCR5: in vivo dynamics of CD4(+) T-cell differentiation in pathogenesis of AIDS. J Virol 1998, 72(12): 10323-I0327.

60. Schnittman SM, Lane HC, Greenhouse J, Justement JS, Baseler M, Fauci AS: Preferential infection of CD4+ memory T cells by human immunodeficiency virus type $\mathrm{I}$ : evidence for a role in the selective T-cell functional defects observed in infected individuals. Proc Natl Acad Sci U S A 1990, 87(16):6058-6062.

61. Kelleher $A D$, Zaunders JJ: Decimated or missing in action: CD4+ $T$ cells as targets and effectors in the pathogenesis of primary HIV infection. Curr HIVIAIDS Rep 2006, 3(I):5-I2.

62. Zaunders JJ, Cunningham PH, Kelleher AD, Kaufmann GR, Jaramillo $A B$, Wright R, Smith D, Grey P, Vizzard J, Carr A, Cooper DA: Potent antiretroviral therapy of primary human immunodeficiency virus type I (HIV-I) infection: partial normalization of $T$ lymphocyte subsets and limited reduction of HIV-I DNA despite clearance of plasma viremia. J Infect Dis 1999 , I 80(2):320-329.

63. O'Brien SJ, Moore JP: The effect of genetic variation in chemokines and their receptors on HIV transmission and progression to AIDS. Immunol Rev 2000, I77:99-III.

64. Roger M: Influence of host genes on HIV-I disease progression. Faseb J 1998, 12(9):625-632

65. Hazenberg MD, Hamann D, Schuitemaker H, Miedema F: T cell depletion in HIV-I infection: how CD4+ $T$ cells go out of stock. Nat Immunol 2000, I(4):285-289.

66. McCune JM: The dynamics of CD4+ T-cell depletion in HIV disease. Nature 200I, 4I 0(683 I):974-979.

67. Alexander L, Illyinskii PO, Lang SM, Means RE, Lifson J, Mansfield K, Desrosiers RC: Determinants of increased replicative capacity of serially passaged simian immunodeficiency virus with nef deleted in rhesus monkeys. I Virol 2003, 77( I 2):6823-6835.

68. Churchill MJ, Figueiredo A, Cowley D, Gray L, Purcell DF, Sullivan JS, McPhee DA, Wesselingh SL, Brew BJ, Gorry PR: Transcriptional activity of blood-and cerebrospinal fluid-derived nef/longterminal repeat sequences isolated from a slow progressor infected with nef-deleted human immunodeficiency virus type I (HIV-I) who developed HIV-associated dementia. Neurovirol 2006, I 2(3):219-228.

69. Jeeninga RE, Hoogenkamp M, Armand-Ugon M, de Baar M, Verhoef $K$, Berkhout B: Functional differences between the long terminal repeat transcriptional promoters of human immunodeficiency virus type I subtypes A through G. J Virol 2000, 74(8):3740-375।.

70. Gorry P, Purcell D, Howard J, McPhee D: Restricted HIV-I infection of human astrocytes: potential role of nef in the regulation of virus replication. Journal of Neurovirology 1998 , 4(4):377-386.

71. Shioda T, Oka S, Xin X, Liu H, Harukuni R, Kurotani A, Fukushima M, Hasan MK, Shiino T, Takebe $Y$, Iwamoto A, Nagai $Y$ : In vivo sequence variability of human immunodeficiency virus type I envelope gp | 20: association of V2 extension with slow disease progression. J Virol 1997, 7 I(7):487I-488I.

72. Wang B, Spira T], Owen S, Lal RB, Saksena NK: HIV-I strains from a cohort of American subjects reveal the presence of a V2 region extension unique to slow progressors and non-progressors. Aids 2000, I 4(3):2/3-223.

73. Iversen AK, Shpaer EG, Rodrigo AG, Hirsch MS, Walker BD, Sheppard HW, Merigan TC, Mullins Jl: Persistence of attenuated rev genes in a human immunodeficiency virus type I-infected asymptomatic individual. J Virol 1995, 69(9):5743-5753.

74. Alexander L, Aquino-Delesus MJ, Chan M, Andiman WA: Inhibition of human immunodeficiency virus type I (HIV-I) replication by a two-amino-acid insertion in HIV-I Vif from a nonprogressing mother and child. J Virol 2002, 76(20): 10533-10539.

75. Binley JM, Jin X, Huang Y, Zhang L, Cao Y, Ho DD, Moore JP: Persistent antibody responses but declining cytotoxic T-lymphocyte responses to multiple human immunodeficiency virus type $I$ antigens in a long-term nonprogressing individual with a defective p 17 proviral sequence and no detectable viral RNA expression. J Virol 1998, 72(4):3472-3474.

76. Wang B, Ge YC, Palasanthiran P, Xiang SH, Ziegler J, Dwyer DE, Randle C, Dowton D, Cunningham A, Saksena NK: Gene defects clustered at the C-terminus of the vpr gene of HIV-I in longterm nonprogressing mother and child pair: in vivo evolution of vpr quasispecies in blood and plasma. Virology 1996, 223(I):224-232. 
77. Yamada T, Iwamoto A: Comparison of proviral accessory genes between long-term nonprogressors and progressors of human immunodeficiency virus type I infection. Arch Virol 2000, I 45(5): I $021-1027$.

78. Michael NL, Chang G, d'Arcy LA, Ehrenberg PK, Mariani R, Busch MP, Birx DL, Schwartz DH: Defective accessory genes in a human immunodeficiency virus type I-infected long-term survivor lacking recoverable virus. J Virol 1995, 69(7):4228-4236.

79. Hua J, Caffrey JJ, Cullen BR: Functional consequences of natural sequence variation in the activation domain of HIV-I Rev. Virology 1996, 222(2):423-429.

80. Smith SM, Pentlicky S, Klase Z, Singh M, Neuveut C, Lu CY, Reitz MS Jr., Yarchoan R, Marx PA, Jeang KT: An in vivo replication-important function in the second coding exon of Tat is constrained against mutation despite cytotoxic $\mathrm{T}$ lymphocyte selection. J Biol Chem 2003, 278(45):44816-44825.

8I. Churchill M, Chiavaroli L, Wesselingh SL, Gorry PR: Persistence of attenuated HIV-I rev alleles in an epidemiologically linked cohort of long-term survivors infected with nef-deleted virus. Retrovirology 2007, 4:43.

82. Adalid-Peralta L, Grangeot-Keros L, Rudent A, Ngo-Giang-Huong N, Krzysiek R, Goujard C, Deveau C, Le Gall M, Meyer L, Emilie D, Rouzioux C: Impact of highly active antiretroviral therapy on the maturation of anti-HIV-I antibodies during primary HIVI infection. HIV Med 2006, 7(8):5 I 4-5 I9.

83. Wilson KM, Johnson El, Croom HA, Richards KM, Doughty L, Cunningham PH, Kemp BE, Branson BM, Dax EM: Incidence immunoassay for distinguishing recent from established HIV-I infection in therapy-naive populations. Aids 2004, I 8(I7):2253-2259.

84. Carotenuto P, Looij D, Keldermans L, de Wolf F, Goudsmit J: Neutralizing antibodies are positively associated with CD4+ $T$ cell counts and T-cell function in long-term AIDS-free infection. Aids 1998, I2(13):159|-1600.

85. Pilgrim AK, Pantaleo G, Cohen OJ, Fink LM, Zhou JY, Zhou JT, Bolognesi DP, Fauci AS, Montefiori DC: Neutralizing antibody responses to human immunodeficiency virus type $I$ in primary infection and long-term-nonprogressive infection. J Infect Dis 1997, 176(4):924-932.

86. Zhang YJ, Fracasso C, Fiore JR, Bjorndal A, Angarano G, Gringeri A, Fenyo EM: Augmented serum neutralizing activity against primary human immunodeficiency virus type I (HIV-I) isolates in two groups of HIV-I-infected long-term nonprogressors. J Infect Dis 1997, I76(5): I I80-I I87.

87. Cranage MP, Whatmore AM, Sharpe SA, Cook N, Polyanskaya N, Leech S, Smith JD, Rud EW, Dennis MJ, Hall GA: Macaques infected with live attenuated SIVmac are protected against superinfection via the rectal mucosa. Virology 1997, 229(I): I 43-154.

88. Enose Y, Ui M, Miyake A, Suzuki H, Uesaka H, Kuwata T, Kunisawa J, Kiyono $\mathrm{H}$, Takahashi H, Miura T, Hayami M: Protection by intranasal immunization of a nef-deleted, nonpathogenic SHIV against intravaginal challenge with a heterologous pathogenic SHIV. Virology 2002, 298(2):306-316.

89. Igarashi $T, A m i$, Yamamoto H, Shibata R, Kuwata T, Mukai R, Shinohara K, Komatsu T, Adachi A, Hayami M: Protection of monkeys vaccinated with vpr- and/or nef-defective simian immunodeficiency virus strain mac/human immunodeficiency virus type I chimeric viruses: a potential candidate live-attenuated human AIDS vaccine. J Gen Virol 1997, 78 ( Pt 5):985-989.

90. Kumar A, Mukherjee S, Shen J, Buch S, Li Z, Adany I, Liu Z, Zhuge W, Piatak M Jr., Lifson J, McClure $\mathrm{H}$, Narayan O: Immunization of macaques with live simian human immunodeficiency virus (SHIV) vaccines conferred protection against AIDS induced by homologous and heterologous SHIVs and simian immunodeficiency virus. Virology 2002, 30 I(2): 189-205.

91. Montefiori DC, Baba TW, Li A, Bilska M, Ruprecht RM: Neutralizing and infection-enhancing antibody responses do not correlate with the differential pathogenicity of SIVmac239delta3 in adult and infant rhesus monkeys. J Immunol 1996, I 57( I 2):5528-5535.

92. Stipp HL, Kumar A, Narayan O: Characterization of immune escape viruses from a macaque immunized with live-virus vaccine and challenged with pathogenic SHIVKU-I. AIDS Res Hum Retroviruses 2000, I6(15): 1573-1580.

93. Greenough TC, Somasundaran M, Brettler DB, Hesselton RM, Alimenti A, Kirchhoff F, Panicali D, Sullivan JL: Normal immune func- tion and inability to isolate virus in culture in an individual with long-term human immunodeficiency virus type I infection. AIDS Res Hum Retroviruses 1994, 10(4):395-403.

94. Qiao X, He B, Chiu A, Knowles DM, Chadburn A, Cerutti A: Human immunodeficiency virus I Nef suppresses CD40-dependent immunoglobulin class switching in bystander B cells. Nat Immunol 2006, 7(3):302-310.

95. Pontesilli O, Klein MR, Kerkhof-Garde SR, Pakker NG, de Wolf $F$, Schuitemaker $\mathrm{H}$, Miedema $\mathrm{F}$ : Longitudinal analysis of human immunodeficiency virus type I-specific cytotoxic $T$ lymphocyte responses: a predominant gag-specific response is associated with nonprogressive infection. J Infect Dis 1998, 178(4): $1008-1018$.

96. Riviere $Y$, McChesney MB, Porrot F, Tanneau-Salvadori F, Sansonetti P, Lopez O, Pialoux G, Feuillie V, Mollereau M, Chamaret S, et al: Gag-specific cytotoxic responses to HIV type I are associated with a decreased risk of progression to AIDS-related complex or AIDS. AIDS Res Hum Retroviruses 1995, I I (8):903-907.

97. Geldmacher C, Currier JR, Herrmann E, Haule A, Kuta E, McCutchan F, Njovu L, Geis S, Hoffmann O, Maboko L, Williamson C, Birx D, Meyerhans A, Cox J, Hoelscher M: CD8 T-cell recognition of multiple epitopes within specific Gag regions is associated with maintenance of a low steady-state viremia in human immunodeficiency virus type I-seropositive patients. J Virol 2007, 8 I(5):2440-2448.

98. Dyer WB, Ogg GS, Demoitie MA, Jin X, Geczy AF, Rowland-Jones SL, McMichael AJ, Nixon DF, Sullivan JS: Strong human immunodeficiency virus (HIV)-specific cytotoxic T-lymphocyte activity in Sydney Blood Bank Cohort patients infected with nefdefective HIV type I. J Virol 1999, 73(I):436-443.

99. Dyer WB, Geczy AF, Kent SJ, McIntyre LB, Blasdall SA, Learmont JC, Sullivan JS: Lymphoproliferative immune function in the Sydney Blood Bank Cohort, infected with natural nef/long terminal repeat mutants, and in other long-term survivors of transfusion-acquired HIV-I infection. Aids 1997, II(I3): I565-1574.

100. Dyer WB, Kuipers H, Coolen MW, Geczy AF, Forrester J, Workman $\mathrm{C}$, Sullivan JS: Correlates of antiviral immune restoration in acute and chronic HIV type I infection: sustained viral suppression and normalization of $\mathbf{T}$ cell subsets. AIDS Res Hum Retroviruses 2002, 18(14):999-1010.
Publish with BioMed Central and every scientist can read your work free of charge

"BioMed Central will be the most significant development for disseminating the results of biomedical research in our lifetime. "

Sir Paul Nurse, Cancer Research UK

Your research papers will be:

- available free of charge to the entire biomedical community

- peer reviewed and published immediately upon acceptance

- cited in PubMed and archived on PubMed Central

- yours - you keep the copyright

Submit your manuscript here:

http://www.biomedcentral.com/info/publishing_adv.asp
BioMedcentral 